\title{
Determination of antibacterial activity and minimum inhibitory concentration of larval extract of fly via resazurin-based turbidometric assay
}

Chien Huey Teh* ${ }^{*}$, Wasi Ahmad Nazni, Ab Hamid Nurulhusna, Ahmad Norazah and Han Lim Lee

\begin{abstract}
Background: Antimicrobial resistance is currently a major global issue. As the rate of emergence of antimicrobial resistance has superseded the rate of discovery and introduction of new effective drugs, the medical arsenal now is experiencing shortage of effective drugs to combat diseases, particularly against diseases caused by the dreadful multidrug-resistant strains, such as the methicillin-resistant Staphylococcus aureus (MRSA). The ability of fly larvae to thrive in septic habitats has prompted us to determine the antibacterial activity and minimum inhibitory concentrations (MICS) of larval extract of flies, namely Lucilia cuprina, Sarcophaga peregrina and Musca domestica against 4 pathogenic bacteria [Staphylococcus aureus, methicillin-resistant S. aureus (MRSA), Pseudomonas aeruginosa and Escherichia coli] via a simple and sensitive antibacterial assay, resazurin-based turbidometric (TB) assay as well as to demonstrate the preliminary chemical profile of larval extracts using gas chromatography-mass spectrophotometry (GC-MS).

Results: The resazurin-based TB assay demonstrated that the L. cuprina larval extract was inhibitory against all tested bacteria, whilst the larval extract of $\mathrm{S}$. peregrina and $\mathrm{M}$. domestica were only inhibitory against the MRSA, with a MIC of $100 \mathrm{mg} \mathrm{ml}^{-1}$. Subsequent sub-culture of aliquots revealed that the larval extract of L. cuprina was bactericidal against MRSA whilst the larval extracts of S. peregrina and M. domestica were bacteriostatic against MRSA. The GC-MS analysis had quantitatively identified 20 organic compounds (fatty acids or their derivatives, aromatic acid esters, glycosides and phenol) from the larval extract of L. cuprina; and 5 fatty acid derivatives with known antimicrobial activities from S. peregrina and M. domestica.

Conclusion: The resazurin-based turbidometric assay is a simple, reliable and feasible screening assay which evidently demonstrated the antibacterial activity of all fly larval extracts, primarily against the MRSA. The larval extract of L. cuprina exerted a broad spectrum antibacterial activity against all tested bacteria. The present study revealed probable development and use of novel and effective natural disinfectant(s) and antibacterial agent(s) from flies and efforts to screen more fly species for antibacterial activity using resazurin-based TB assay should be undertaken for initial screening for subsequent discovery and isolation of potential novel antimicrobial substances, particularly against the multi-drug resistant strains.
\end{abstract}

Keywords: Lucilia cuprina, Maggot therapy, Antibacterial activity, Resazurin, MRSA

\footnotetext{
* Correspondence: chienhuey@imr.gov.my

Medical Entomology Unit, Infectious Disease Research Centre, Institute for

Medical Research, Jalan Pahang, Kuala Lumpur 50588, Malaysia
} 


\section{Background}

The advent of antibiotics had improved mankind's health status and quality of life tremendously. However, overuse and misuse of antibiotics had resulted in increased development and occurrence of bacterial resistance against commercially available antibiotics [21]. Therefore, the search for novel antibiotics of natural origins, particularly from marine resources $[5,15]$ and plants $[7,11]$ has been undertaken persistently. Nonetheless, studies which looked into the possibility of discovery of antimicrobial agent(s) from insects are scarce.

Insects, particularly the immature of flies, by nature of their biology and the ability to breed and thrive in septic habitats such as cadavers, carcasses, wounds and decaying organic matters, are infested with a great variety of microorganisms, some of which are pathogens [2]. In order to protect themselves from the undesirable effects of these microbes, insect immatures are known to produce and secrete potent anti-microbial substances $[1,4,10,16,17]$ which may be the potential sources of novel antibiotics, especially for treatment of diseases caused by the multi-drug resistance strains such as the methicillin-resistant Staphylococcus aureus (MRSA).

The promising antibacterial activity of the local blowfly larvae, Lucilia cuprina against a wide range of pathogenic bacteria [19] which had in turn made it an effective medicinal larvae in maggot debridement therapy [13] as well as the ability of fly to thrive in septic environment have prompted our interest to screen the larval extract of other fly species against pathogenic bacteria. For screening purposes, it is essential to employ an in vitro antibacterial assay that is simple, reliable, sensitive, and most importantly, require a minimal amount of crude extract. The inability of turbidometric assay to differentiate dead and alive bacteria as well as the insensitivity of well-diffusion assay [9] had hindered the screening process.

The resazurin-based turbidometric (TB) assay was first used to quantify bacterial content in milk by Pesch and Simmert in 1929 [14]. Resazurin (7-Hydroxy-3H-phenoxazin-3-one 10-oxide) is a blue dye which can be irreversibly reduced to a pink and highly red fluorescent substance, resorufin by oxidoreductase within viable cells. The resorufin can be further reduced to a colorless and non-fluorescent molecule, hydroresorufin. In light of the simplicity and high-throughput of the resazurinbased TB assay, it has been employed in many studies as an antibacterial screening assay (Sarker et al., 2007; [18]; Hussain et al., 2011 [6]; Gahlaut \& Chhillar, 2013; [3]), however, these studies only involved screening of antimicrobial activity of phytochemicals.

Therefore, the present study aimed to determine the antibacterial activity and properties (bactericidal or bacteriostatic) as well as minimum inhibitory concentrations
(MICs) of larval extracts of Lucilia cuprina, Sarcophaga peregrina, and Musca domestica against Staphylococcus aureus, MRSA, Pseudomonas aeruginosa and Escherichia coli via resazurin-based TB assay, as well as to demonstrate the chemical profiles of these larval extracts using gas chromatography-mass spectrophotometry (GC-MS).

\section{Methods}

\section{Larvae}

The fly colonies of Lucilia cuprina, Sarcophaga peregrina and Musca domestica were maintained in the insectarium of Medical Entomology Unit, Institute for Medical Research (IMR), Kuala Lumpur under 12:12 h of light dark cycle at $22 \pm 2{ }^{\circ} \mathrm{C}$ and $77.0 \pm 2.53 \%$ humidity with continuous supply of water and granular sugar. Female flies were provided with raw cow liver (L. cuprina), raw cow lung ( $S$. peregrina) or moistened mouse pellet $(M$. domestica) for oviposition. The resultant eggs were transferred onto fresh pieces of raw cow liver and mouse pellet (L. cuprina), raw cow lung (S. peregrina) or moistened mouse pellet $(M$. domestica) in clean containers and the hatched larvae were constantly supplied with fresh raw cow liver ( $L$. cuprina) or raw cow lung (S. peregrina) and water for development into late second-instar larvae.

\section{Test bacteria}

Staphylococcus aureus ATCC 25923, Methicillinresistant Staphylococcus aureus (MRSA S914, a clinical isolate), Pseudomonas aeruginosa (ATCC 27853) and Escherichia coli (ATCC 25922) were kind gifts from the Bacteriology Unit, IMR, Kuala Lumpur. These bacterial cultures were maintained on blood agar (BA). All work pertaining to the handling of bacterial cultures were performed in a EuroClone ${ }^{\curvearrowleft}$ BioAir $^{\oplus}$ Microbiological Safety Cabinet Class II type A2.

\section{Chemicals}

All chemicals were purchased from Bio-Basic, Canada and Oxoid Ltd (BioFocus Saintifik Sdn.Bhd).

\section{Production of larval extract}

The production of larval extract was performed according to the published protocols by Teh et al. [19] with slight modifications. Approximately 200 unsterile, 2 to 3 daysold fly larvae were collected from cow livers, cow lungs or moistened mouse pellet and transferred into a clean, disinfected $50 \mathrm{ml}$ washing tube. The unsterile larvae were washed with $40 \mathrm{ml}$ of $70 \%$ ethyl alcohol and rinsed three times with sterile distilled water. Washed larvae were blotdried with sterile paper towels and transferred into another clean, disinfected $50 \mathrm{ml}$ washing tube.

Larvae were homogenised with absolute methanol (200 larvae/ $100 \mathrm{ml}$ methanol). The homogenate was then transferred into clean, disinfected $50 \mathrm{ml}$ centrifuge tubes and 
centrifuged at $4000 \mathrm{x} \mathrm{g}$ for $30 \mathrm{~min}$ (Eppendorf Centrifuge 5810R). The resultant yellowish supernatant was collected and transferred into clean, disinfected glass vials. Lastly, the supernatant was concentrated using a centrifugal vacuum concentrator (Genevac miVac Quattro Concentrator) to remove methanol. The vacuum-concentrated product, i.e., the larval extract was weighed before being kept at $-70{ }^{\circ} \mathrm{C}$. Prior to antibacterial assay, $200 \mathrm{mg}$ larval extract was resuspended in $1 \mathrm{ml}$ sterile distilled water and filter-sterilised with Minisart $^{\circ}$ cellulose acetate membrane syringe filter with a pore size of $0.2 \mu \mathrm{m}$.

\section{Preparation of bacterial suspension}

Bacteria stock cultures (S. aureus, MRSA, P. aeruginosa and $E$. coli) were sub-cultured onto BA plates and incubated overnight at $37{ }^{\circ} \mathrm{C}$. The next day, three to four discrete bacterial colonies with similar morphology were inoculated into $10 \mathrm{ml}$ sterile Mueller Hinton broth (MHB) and incubated overnight at $37{ }^{\circ} \mathrm{C}$. The overnight bacterial suspensions were adjusted to 0.5 McFarland Standard with sterile MHB broth. To aid comparison, the adjustment of bacterial suspensions to the density of the 0.5 McFarland Standard was done against a white background with contrasting black lines.

\section{Preparation of resazurin solution}

Resazurin solution was prepared by dissolving $337.5 \mathrm{mg}$ of resazurin powder in $50 \mathrm{ml}$ sterile distilled water in a disinfected beaker. A sterile vortex mixer was used to mix the solution for $1 \mathrm{~h}$ to ensure homogeneity. The preparation procedures were performed in dark and the resazurin solution was then kept in a brown bottle to prevent exposure to light since it is sensitive to light.

\section{Resazurin-based turbidometric assay and Minimum Inhibitory Concentration (MIC) determination}

The resazurin-based turbidometric (TB) assay was adopted to demonstrate the inhibition effects of larval extract of S. peregrina and M. domestica against S. aureus, MRSA, $P$. aeruginosa and $E$. coli. The larval extract of $L$. cuprina was included into the study as another positive control in addition to standard antibiotics since its inhibitory effects had been demonstrated previously by Teh et al. [19] and therefore can validate and corroborate the feasibility of this assay. Broth microdilutions were performed precisely according to the Clinical and Laboratory Standards Institute (CLSI) protocol.

In a 96-well round-bottom microtiter plate, for each bacteria culture, the assay composed of one vertical row of broth sterility control, 3 vertical rows of larval extract sterility control (1 row each for L. cuprina, S. peregrina and $M$. domestica), 1 vertical row of growth control, 1 vertical row of antibiotic control and lastly, 3 vertical rows of larval extract test sample (1 row each for $L$. cuprina, S. peregrina and $M$. domestica). All eight wells in a vertical row were filled with $100 \mathrm{ul} \mathrm{MHB}$. The first well of each vertical row contained $100 \mathrm{ul}$ of sterile distilled water, larval extract of $200 \mathrm{mg} \mathrm{ml}^{-1}$, sterile distilled water, chloramphenicol (for S. aureus and MRSA) or gentamicin (for P. aeruginosa and E.coli) of $100 \mathrm{mg} \mathrm{ml}^{-1}$ and larval extract of $200 \mathrm{mg} \mathrm{ml}^{-1}$ for broth sterility control, larval extract sterility controls, growth control, antibiotic control and larval extract test samples, respectively. Subsequently, the mixture in the first well of each vertical row was mixed thoroughly. Then, a separate and sterile pipette was used to transfer $100 \mu \mathrm{l}$ of mixture in the first well into the second well $\left(2^{-2}\right)$, and mixed thoroughly. Again, $100 \mu \mathrm{l}$ of the mixture was transferred from the second well into the third well $\left(2^{-3}\right)$ and mixed thoroughly. This serial dilution was continued to the eighth well $\left(2^{-8}\right)$. Lastly, $100 \mu$ l was removed from the eighth well and discarded. The final concentration of antibiotics and larval extract was now one-half of the original concentration in each well.

Then, $5 \mu \mathrm{l}$ of diluted bacterial suspension $\left(1.5 \times 10^{6} \mathrm{cell} /\right.$ $\mathrm{ml}$ ) was added into all wells (except the broth sterility and larval extract sterility control column) and mixed thoroughly. Microdilution was performed in triplicates for each bacterial species. After an overnight incubation at $37^{\circ} \mathrm{C}, 5$ ul resazurin $\left(6.75 \mathrm{mg} \mathrm{ml}^{-1}\right)$ was added to all wells and incubated at $37^{\circ} \mathrm{C}$ for another $4 \mathrm{~h}$. Changes of color was observed and recorded. The lowest concentration prior to colour change was considered as the Minimum Inhibitory Concentration (MIC).

Determination of antibacterial properties of larval extract In order to elucidate the antibacterial properties (bactericidal or bacteriostatic) of larval extracts, a loopful of aliquots from the MIC wells was transferred onto brain heart infusion agar (BHIA) and incubated overnight. If bacteria failed to resume growth on BHIA after an overnight incubation, the larval extract was considered to be bactericidal, otherwise, it was bacteriostatic.

\section{Gas Chromatography-Mass Spectrometry (GC-MS)}

To determine the chemical profile of larval extracts, $1.0 \mu \mathrm{l}$ of methanol extract of L. cuprina, S. peregrina and $M$. domestica larvae $(1 \mathrm{mg} / \mathrm{ml})$ was injected into a gas chromatography system (Agilent 7890A) coupled with an inert mass spectrometer (Agilent 5975C) with tripleaxis detector (quadrupole). The separation of larval extract was achieved using a DB5-MS UI capillary column (30 m x $0.25 \mathrm{~mm} \times 0.25 \mu \mathrm{m} ; 5 \%$ polydimethylsiloxane) via an autosampler (CTC Analytics) in splitless mode. Helium was used as the carrier gas with a linear velocity of $1 \mathrm{ml} / \mathrm{min}$. The injector temperature was set at $230{ }^{\circ} \mathrm{C}$ and oven temperature was kept at $70{ }^{\circ} \mathrm{C}$ for $2 \mathrm{~min}$ and then increased to $270{ }^{\circ} \mathrm{C}$ at $20{ }^{\circ} \mathrm{C} / \mathrm{min}$. 


\section{Results}

In the resazurin-based turbidometric (TB) assay, all sterility control wells for all tested bacteria remained as blue colour after an overnight incubation and followed by a 4-h incubation with resazurin. In contrast, all wells in the growth control column (contained growth medium and bacteria) of all tested bacteria had changed from blue to pink colour or from blue to pale pink (Additional files 1, 2, 3 and 4).

Table 1 demonstrated that the minimum inhibitory concentration (MIC) of the positive control, chloramphenicol against $S$. aureus was observed at the sixth well $\left(2^{-6}=\right.$ $1.56 \mathrm{mg} \mathrm{ml}^{-1}$ ) which was the last well prior to the occurrence of colour change. On the other hand, the MIC of the larval extract of $L$. cuprina was observed at the first well $\left(2^{-1}\right)$ which was equivalent to $100 \mathrm{mg} \mathrm{ml}^{-1}$. However, the larval extract of both $S$. peregrina and $M$. domestica were not active against $S$. aureus since all wells in both columns had changed from blue to pale pink, which indicated bacterial growth.

In contrast, the MIC of chloramphenicol against MRSA was as high as $25 \mathrm{mg} \mathrm{ml}^{-1}$ and all larval extracts (L. cuprina, S. peregrina and $M$. domestica) were inhibitory against MRSA at MICs of $100 \mathrm{mg} \mathrm{ml}^{-1}$. On the other hand, for the gram-negative bacteria, $P$. aeruginosa and E. coli, the MICs of gentamicin were $1.56 \mathrm{mg} \mathrm{m}^{-1}$ and $0.78 \mathrm{mg} \mathrm{ml}^{-1}$, respectively. The larval extract of $L$. cuprina was active against both $P$. aeruginosa and $E$. coli at MIC of $100 \mathrm{mg} \mathrm{ml}^{-1}$, however, similar to those observed in S. aureus, larval extracts of S. peregrina and $M$. domestica did not exhibit any antibacterial activity against these gram-negative bacteria. The MICs of standard antibiotics and larval extracts against all tested bacteria were summarised in Table 1.

When aliquots were removed from the corresponding MIC wells of standard antibiotics (gentamicin or chloramphenicol) or L. cuprina larval extract, no bacterial growth was observed for all BHIA plates because bacteria cells were unable to resume growth (Additional file 5). However, aliquots of MRSA resumed growth on BHIA plates after it was removed from the MIC wells of S. peregrina and $M$. domestica larval extract (Additional file 6) though the resazurin-based $\mathrm{TB}$ assay demonstrating that the growth of MRSA was inhibited.

The GC-MS analysis had quantitatively identified as many as 20 organic compounds from the larval extract of $L$. cuprina and 17 of them were fatty acids or their derivatives (Table 2). Amongst these 20 compounds, $\alpha$-Methyl-D-mannoside $(18.41 \%)$ was found to be the most dominant compound, followed by hydroxypropyl ester of oleic acid (15.52\%), oleic acid (8.20\%), Methyl $\alpha$-D-galactoside $(7.25 \%)$ and palmitic acid (7.11\%). The other compounds were present in trace amount (less than 5\%). In contrast, only 5 compounds, of which all were methyl ester of fatty acids (palmitic acid, oleic acid, palmitoleic acid, myristic acid and linoleic acid) which were also present in the larval extract of L. cuprina were identified from the larval extracts of S. peregrina and M. domestica (Table 3).

\section{Discussion}

In resazurin-based TB assay, viable and metabolically active bacteria cells irreversibly reduced the blue dye, resazurin to a pink and highly red fluorescent compound, resorufin and finally to a colourless and non-fluorescent molecule, hydroresorufin by oxidoreductase [8]. Such change of colour can be observed visually and therefore spectrophotometer is not needed in this assay as compared to the conventional TB assay.

Generally, the larval extract of L. cuprina was inhibitory against all tested bacteria, whilst the larval extract of $S$. peregrina and $M$. domestica were only active against MRSA. The broad spectrum inhibitory effects of the larval extract of $L$. cuprina against all tested bacteria in the resazurin-based TB assay were in agreement with those reported by Teh et al. [19] who employed conventional TB assay, and this again substantiated that the resazurin-based TB assay generated comparable results with the conventional TB assay and therefore can be considered as a simple, reliable and feasible antibacterial assay since it does not require a spectrophotometer to determine the bacterial growth. On the other hand, it was noteworthy that the MICs of L. cuprina larval extract as determined in the present study $\left(100 \mathrm{mg} \mathrm{ml}^{-1}\right)$ was relatively higher than those reported by Teh et al. [19]. The inconsistency in the MICs value though using the same fly species (L. cuprina) could be due to different definitions of MIC. Teh et al. [19] defined the MIC endpoints of larval extract against bacteria as the lowest concentration of larval extract $\left(\mathrm{mg} \mathrm{ml}^{-1}\right)$ resulting in at least $50 \%$ bacterial growth inhibition relative to that of the corresponding controls. In contrast, the present

Table 1 MICs of standard antibiotics and larval extracts against bacteria

\begin{tabular}{|c|c|c|c|c|}
\hline \multirow[t]{2}{*}{ Bacteria } & \multirow{2}{*}{$\begin{array}{l}\text { Antibiotics } \\
\left(100 \mathrm{mg} \mathrm{ml}^{-1}\right)\end{array}$} & \multicolumn{3}{|c|}{ Larval Extracts $\left(200 \mathrm{mg} \mathrm{m}^{-1}\right)$} \\
\hline & & L. cuprina & S. peregrina & M. domestica \\
\hline S. aureus & Chloramphenicol 1.56 & 100.0 & - & - \\
\hline MRSA & Chloramphenicol 25.0 & 100.0 & 100.0 & 100.0 \\
\hline P. aeruginosa & Gentamicin 1.56 & 100.0 & - & - \\
\hline E. coli & Gentamicin 0.78 & 100.0 & - & - \\
\hline
\end{tabular}


Table 2 Chemical components of the methanol extract of larvae of Lucilia cuprina

\begin{tabular}{|c|c|c|c|c|}
\hline $\begin{array}{l}\text { Retention } \\
\text { Time (Min) }\end{array}$ & $\begin{array}{l}\text { Content } \\
(\%)\end{array}$ & Compound Name (NIST Library) & $\begin{array}{l}\text { Chemical Formula/ Molecular } \\
\text { Weight }(\mathrm{g} / \mathrm{mol})\end{array}$ & Compound Nature \\
\hline 9.568 & 1.38 & Phenol, 2,4-bis(1,1-dimethylethyl)- & $\mathrm{C}_{14} \mathrm{H}_{22} \mathrm{O} / 206.32$ & Phenolic compound \\
\hline 10.621 & 7.25 & Methyl a-D-galactopyranoside & $\mathrm{C}_{7} \mathrm{H}_{14} \mathrm{O}_{6} / 194.18$ & Glycoside \\
\hline 10.892 & 18.41 & Methyl a-D-mannopyranoside & $\mathrm{C}_{7} \mathrm{H}_{14} \mathrm{O}_{6} / 194.18$ & Glycoside \\
\hline 12.118 & 0.84 & Methyl tetradecanoate & $\mathrm{C}_{15} \mathrm{H}_{30} \mathrm{O}_{2} / 242.40$ & $\begin{array}{l}\text { Fatty acid methyl ester (myristic acid } \\
\text { methyl ester) }\end{array}$ \\
\hline 12.474 & 0.34 & Tetradecanoic acid & $\mathrm{C}_{14} \mathrm{H}_{28} \mathrm{O}_{2} / 228.37$ & Fatty acid (myristic acid) \\
\hline 14.035 & 2.64 & 9-hexadecenoic acid, methyl ester & $\mathrm{C}_{17} \mathrm{H}_{32} \mathrm{O}_{2} / 268.43$ & $\begin{array}{l}\text { Fatty acid methyl ester (palmitoleic acid } \\
\text { methyl ester) }\end{array}$ \\
\hline 14.246 & 4.47 & Hexadecanoic acid, methyl ester & $\mathrm{C}_{17} \mathrm{H}_{34} \mathrm{O}_{2} / 270.45$ & $\begin{array}{l}\text { Fatty acid methyl ester (palmitic acid } \\
\text { methyl ester) }\end{array}$ \\
\hline 14.322 & 0.39 & $\begin{array}{l}\text { Benzenepropanoic acid, 3,5-bis (1,1- } \\
\text { dimethyethyl)-4-hydroxy-, methyl ester }\end{array}$ & $\mathrm{C}_{18} \mathrm{H}_{28} \mathrm{O}_{3} / 292.41$ & Aromatic acid ester \\
\hline 14.403 & 2.81 & Cis-9-hexadecenoic acid & $\mathrm{C}_{16} \mathrm{H}_{30} \mathrm{O}_{2} / 254.41$ & Fatty acid (isomer of palmitoleic acid) \\
\hline 14.608 & 7.11 & n-Hexadecanoic acid & $\mathrm{C}_{16} \mathrm{H}_{32} \mathrm{O}_{2} / 256.42$ & Fatty acid (palmitic acid) \\
\hline 15.894 & 2.13 & 9,12-octadecadienoic acid $(z, z)-$-, methyl ester & $\mathrm{C}_{19} \mathrm{H}_{34} \mathrm{O}_{2} / 294.47$ & $\begin{array}{l}\text { Fatty acid methyl ester (linoleic acid } \\
\text { methyl ester) }\end{array}$ \\
\hline 15.959 & 3.91 & 9-octadecenoic acid (z)-, methyl ester & $\mathrm{C}_{19} \mathrm{H}_{36} \mathrm{O}_{2} / 296.49$ & $\begin{array}{l}\text { Fatty acid methyl ester (oleic acid methyl } \\
\text { ester) }\end{array}$ \\
\hline 16.256 & 1.53 & 9,12-octadecadienoic acid $(z, z)-$ & $\mathrm{C}_{18} \mathrm{H}_{32} \mathrm{O}_{2} / 280.45$ & Fatty acid (linoleic acid) \\
\hline 16.320 & 8.20 & Oleic acid & $\mathrm{C}_{18} \mathrm{H}_{34} \mathrm{O}_{2} / 282.46$ & Fatty acid \\
\hline 16.515 & 1.55 & Cis-vaccenic acid & $\mathrm{C}_{18} \mathrm{H}_{34} \mathrm{O}_{2} / 282.46$ & Fatty acid (isomer of oleic acid) \\
\hline 17.401 & 0.19 & $\begin{array}{l}\text { 5,8,1 1,14-eicosatetraenoic acid, methyl ester (all- } \\
\text { z)- }\end{array}$ & $\mathrm{C}_{21} \mathrm{H}_{34} \mathrm{O}_{2} / 318.49$ & $\begin{array}{l}\text { Fatty acid methyl ester (arachidonic acid } \\
\text { methyl ester) }\end{array}$ \\
\hline 19.594 & 3.93 & $\begin{array}{l}\text { Hexadecanoic acid, 2-hydroxy-1-(hydroxymethyl) } \\
\text { ethyl ester }\end{array}$ & $\mathrm{C}_{19} \mathrm{H}_{38} \mathrm{O}_{4} / 330.50$ & $\begin{array}{l}\text { Fatty acid ethyl ester of glycerol (Palmitic } \\
\text { acid } \beta \text {-monoglyceride) }\end{array}$ \\
\hline 19.762 & 0.72 & $\begin{array}{l}\text { 1,2-benzenedicarboxylic acid, mono(2- } \\
\text { ethylhexyl) ester }\end{array}$ & $\mathrm{C}_{16} \mathrm{H}_{22} \mathrm{O}_{4} / 278.34$ & Benzoic acid \\
\hline 21.182 & 15.52 & Oleic acid, 3-hydroxypropyl ester & $\mathrm{C}_{21} \mathrm{H}_{40} \mathrm{O}_{3} / 340.54$ & Fatty acid ester \\
\hline 21.388 & 2.83 & Octadecanoic acid, 2,3-dihydroxypropyl ester & $\mathrm{C}_{21} \mathrm{H}_{42} \mathrm{O}_{4} / 358.56$ & $\begin{array}{l}\text { Fatty acid ester of glycerol (Stearic acid a- } \\
\text { monoglyceride) }\end{array}$ \\
\hline
\end{tabular}

study defined MIC as the lowest concentration of larval extract resulting in color change (from blue to pink) or resazurin reduction. Since reduction of resazurin could only performed by viable bacterial cells, therefore, the MICs determined by the resazurin-based TB assay were relatively higher as compared to those determined via conventional TB assay [19] because more larval extract was required to inhibit bacterial growth to less than 80 bacterial cells ([12] had demonstrated that visible change of color from blue to pink can be detected in as few as 80 cells). Besides, the use of heavier bacterial inoculum in the present study i.e. $1.5 \times 10^{6}$ colony-forming unit/

Table 3 Chemical components of the methanol extract of larvae of Sarcophaga peregrina and Musca domestica

\begin{tabular}{|c|c|c|c|c|}
\hline $\begin{array}{l}\text { Retention Time } \\
\text { (Min) }\end{array}$ & $\begin{array}{l}\text { Content } \\
(\%)\end{array}$ & Compound Name (NIST Library) & $\begin{array}{l}\text { Chemical Formula/ Molecular Weight } \\
(\mathrm{g} / \mathrm{mol})\end{array}$ & Compound Nature \\
\hline 12.115 & 4.05 & Methyl tetradecanoate & $\mathrm{C}_{15} \mathrm{H}_{30} \mathrm{O}_{2} / 242.40$ & $\begin{array}{l}\text { Fatty acid methyl ester (myristic acid } \\
\text { methyl ester) }\end{array}$ \\
\hline 14.038 & 8.36 & $\begin{array}{l}\text { 9-hexadecenoic acid, methyl } \\
\text { ester }\end{array}$ & $\mathrm{C}_{17} \mathrm{H}_{32} \mathrm{O}_{2} / 268.43$ & $\begin{array}{l}\text { Fatty acid methyl ester (palmitoleic acid } \\
\text { methyl ester) }\end{array}$ \\
\hline 14.249 & 36.78 & $\begin{array}{l}\text { Hexadecanoic acid, methyl } \\
\text { ester }\end{array}$ & $\mathrm{C}_{17} \mathrm{H}_{34} \mathrm{O}_{2} / 270.45$ & $\begin{array}{l}\text { Fatty acid methyl ester (palmitic acid } \\
\text { methyl ester) }\end{array}$ \\
\hline 15.891 & 2.96 & 9,12-octadecadienoic acid (z,z)- & $\mathrm{C}_{18} \mathrm{H}_{32} \mathrm{O}_{2} / 280.45$ & Fatty acid (linoleic acid) \\
\hline 15.956 & 10.29 & $\begin{array}{l}\text { 9-octadecenoic acid (z)-, } \\
\text { methyl ester }\end{array}$ & $\mathrm{C}_{19} \mathrm{H}_{36} \mathrm{O}_{2} / 296.49$ & $\begin{array}{l}\text { Fatty acid methyl ester (oleic acid methyl } \\
\text { ester) }\end{array}$ \\
\hline
\end{tabular}


$\mathrm{ml}(\mathrm{CFU} / \mathrm{ml})$ compared to only $1.0 \times 10^{2} \mathrm{CFU} / \mathrm{ml}$ in the previous study by Teh et al. [19] may also attribute to the discrepancy in MICs.

To the best of the author's knowledge, the inhibitory effect as well as the MICs of the S. peregrina and $M$. domestica larval extract against MRSA had never been determined. The apparent potency of the L. cuprina, $S$. peregrina and $M$. domestica larval extract against MRSA provided promising input for probable identification, isolation and purification of novel effective antibacterial compound(s) of natural origin, particularly to combat the dreadful bacterial strain, MRSA.

On the other hand, the inactivity of $M$. domestica larval extract against $S$. aureus, $P$. aeruginosa and $E$. coli was not in agreement with those reported by other investigators. Golebiowski et al. [4] who had successfully identified 7 compounds from the larvae of $M$. domestica had revealed that 2,4-decadienal exhibited the strongest antibacterial activity among the other 6 compounds, with MIC of $64 \mathrm{mg} \mathrm{ml}^{-1}$ against S. aureus and $512 \mathrm{mg} \mathrm{ml}^{-1}$ against $P$. aeruginosa and $E$. coli. The discrepancies between the present study and those reported by Golebiowski et al. [4] could be partly due to a lower bacterial inoculum tested $\left(5 \times 10^{5} \mathrm{CFU} / \mathrm{ml}\right)$ and also the employment of different antibacterial assay [turbidometric assay in the study by Golebiowski et al. [4]. In the study by Golebiowski et al. [4], the MICs of active compounds were defined as the lowest concentration of active compound at which growth inhibition was clearly visible (absence of turbidity and a pellet at the bottom of the well). Such MIC determination method could result in overestimating the inhibitory effects of the active compounds since visual absence of turbidity and a pellet at the bottom of the well may not guarantee bacterial inhibition as bacterial growth can still occur microscopically. On the other hand, for resazurin-based TB assay, the reduction of resazurin to resorufin by viable cells which in turn lead to visible change of color from blue to pink can be detected in as few as 80 cells [12] and therefore reduced the likelihood of overestimating the inhibitory effect of larval extract.

In terms of antibacterial properties, the inability of bacterial cells to resume growth on the brain heart infusion agar (BHIA) after being transferred from the MIC wells indicated that the standard antibiotics (chloramphenicol for S. aureus and MRSA; gentamicin for $P$. aeruginosa and E.coli) and L. cuprina larval extract were indeed bactericidal against all tested bacteria at the corresponding MICs. On the other hand, larval extracts of $S$. peregrina and $M$. domestica larval extract were unable to suppress the growth of MRSA on BHIA and this signposted that the larval extracts of $S$. peregrina and $M$. domestica exerted bacteriostatic effect against MRSA. Although larval extracts exhibited different properties of antibacterial activity (bactericidal or bacteriostatic) against bacteria, the clinical importance of bacteriostatic versus bactericidal effect on microorganisms is under dispute. Therefore, when screening potential substances for antibacterial activity, the antibacterial properties (bactericidal or bacteriostatic) of that particular substance should never be used to rule out its potential value as an efficient antibacterial drug. It should also be noted that although the MICs of larval extract were higher than the MICs of standard antibiotics, the standard antibiotics were composed of purified active ingredients as compared to the crude extracts of fly larvae. Therefore, a smaller amount of larval extract is expected to exhibit the antibacterial activity if the purified form of larval extract could be produced which would serve as the leads for synthesis of novel antimicrobial products of natural origin.

The chemical analysis of larval extracts revealed that fatty acids were the dominant compounds. Fatty acids had been reported to inhibit bacterial growth by disruption of bacterial membranes or inhibition of fatty acid synthesis [20]. Zheng et al. [22] reported that long chain unsaturated fatty acids such as oleic acid, linoleic acid, palmitoleic acid and arachidonic acid inhibited bacterial growth (S. aureus) by inhibiting the bacterial enoyl-acyl carrier protein reductase (FabI), which is an essential components of bacterial fatty acid synthesis. Therefore, it is not surprising that the antibacterial activities of larval extracts were contributed by the combination of fatty acids. This may partly explains the apparent potency of $L$. cuprina larval extract as compared to the larval extracts of $S$. peregrina and $M$. domestica since it contained more fatty acids. Nonetheless, one should underscore that these preliminary GC-MS analysis only demonstrated the chemical profile of non-volatile compounds from the larval extracts, in order not to overlook the other volatile compounds which may have antibacterial activities, future work to derivatise the larval extract using silylating reagent such as $\mathrm{N}, \mathrm{O}$-bis(trimethylsilyl) trifluoroacetamide (BSTFA) should be undertaken for potential identification and isolation of novel antimicrobial substance(s). Once these compounds have been identified, their antibacterial activity will be tested, both singly and in combinations in the future studies. Subsequently, the cytotoxicity of these compounds on mammalian cell lines will also be assessed to warrant safe use of these compounds in human.

\section{Conclusions}

In short, the resazurin-based turbidometric assay is a simple, reliable and feasible screening assay in assessing the antibacterial activity of larval extract of flies. This assay evidently demonstrated the antibacterial activity of $L$. cuprina, S. peregrina and $M$. domestica larval extracts against MRSA, with $L$. cuprina exerted the broadest antibacterial activity against both gram-positive (S. aureus and 
MRSA) and gram-negative bacteria ( $P$. aeruginosa and $E$. coli). The present study also revealed a potential room for the development of novel and effective natural disinfec$\operatorname{tant}(\mathrm{s})$ and antibacterial agent(s) from flies. Further work of derivatisation and characterization of the larval extract samples to retrieve other non-volatile compounds is greatly warranted to produce a detailed chemical profile as an informative guidance for subsequent identification of antibacterial compound(s). In addition, additional work to screen more fly species using resazurin-based TB assay for screening of antimicrobial activity for probable identification and isolation of potential antimicrobial substances should also be undertaken. If successful, these isolated and purified active substances may then be used as an alternative for maggot debridement therapy for entomophobia patients as well as in combating the increasing threat of emergence of multidrug resistance bacterial strains, particularly the MRSA.

\section{Additional file}

Additional file 1: $S$. aureus microtiter plate after an overnight incubation and addition of resazurin dye $(B=$ broth sterility control; $L C=L$. cuprina larval extract sterility control; $\mathrm{SP}=\mathrm{S}$. peregrina larval extract sterility control and $\mathrm{MD}$ $=M$. domestica larval extract sterility control; $\mathrm{G}=$ growth control; $\mathrm{Ab}=$ chloramphenicol; yellow circle indicates the MIC). (EPS $13.9 \mathrm{mb}$ )

Additional file 2: MRSA microtiter plate after an overnight incubation and addition of resazurin dye $(B=$ broth sterility control; $L C=L$. cuprina larval extract sterility control; $\mathrm{SP}=\mathrm{S}$. peregrina larval extract sterility control and $\mathrm{MD}=\mathrm{M}$. domestica larval extract sterility control; $\mathrm{G}=$ growth control; $\mathrm{Ab}=$ chloramphenicol; yellow circle indicates the MIC). (EPS $13 \mathrm{mb}$ )

Additional file 3: $P$. aeruginosa microtiter plate after an overnight incubation and addition of resazurin dye $(B=$ broth sterility control; $L C=L$. cuprina larval extract sterility control; $S P=S$. peregrina larval extract sterility control and $\mathrm{MD}=\mathrm{M}$. domestica larval extract sterility control; $\mathrm{G}=$ growth control; $\mathrm{Ab}=$ gentamicin; yellow circle indicates the MIC). (EPS $14.3 \mathrm{mb}$ )

Additional file 4: $E$. coli microtiter plate after an overnight incubation and addition of resazurin dye $(B=$ broth sterility control; $L C=L$. cuprina larval extract sterility control; $\mathrm{SP}=\mathrm{S}$. peregrina larval extract sterility control and $\mathrm{MD}=\mathrm{M}$. domestica larval extract sterility control; $\mathrm{G}=$ growth control; $\mathrm{Ab}=$ gentamicin; yellow circle indicates the MIC). (EPS $16.9 \mathrm{mb}$ )

Additional file 5: Bactericidal effects of standard antibiotics and $L$. cuprina larval extract against all tested bacteria. The left column of BHIA plates were inoculated with aliquots from the MIC wells of the corresponding standard antibiotics (gentamicin or chloramphenicol) for each tested bacteria (P. aeruginosa, E. coli, S. aureus and MRSA) whilst the right column of BHIA plates were inoculated with aliquots from the MIC wells of L. cuprina larval extract for each tested bacteria (S. aureus, MRSA, P. aeruginosa and E. coli). (EPS $8.88 \mathrm{mb}$ )

Additional file 6: Apparent potency of $L$. cuprina larval extract against MRSA. The brain-heart infusion agar (BHIA) plate was inoculated with a loop-full of aliquots from the MIC wells of L. cuprina (upper left), S. peregrina (upper right) and $M$. domestica (middle bottom) larval extract against MRSA after an overnight incubation. (EPS $8.67 \mathrm{mb}$ )

\section{Abbreviations}

BSTFA: N,O-bis(trimethylsilyl) trifluoroacetamide; CLSI: Clinical and Laboratory Standards Institute; FAMEs: Fatty acid methyl esters; GC-MS: Gas chromatography mass spectrometry; IMR: Institute for Medical Research; MIC: Minimum Inhibitory Concentration; MRSA: methicillin-resistant Staphylococcus aureus; TB: Turbidometric assay

\section{Acknowledgements}

The authors would like to thank the Director General of Health, Malaysia for his permission to publish this study and the Director, Institute for Medical Research, Kuala Lumpur, Malaysia for support. We would also like to convey our sincerest tribute to Mr Hazmizam Hamzah, Ms Wan Nur Alia Fatin Wan Zahari and Mr Mohd Afiq Mohd Shah for the kind supply of fly larvae as well as the Head of Bacteriology Unit, IMR for the provision of bacteria cultures.

\section{Funding}

This research was supported by the Research and Development Fund, Ministry of Health Malaysia (NMRR-15-2024-27487).

\section{Availability of data and material}

The datasets generated during the present study are not publicly available due to government policies. Data are however available from the corresponding author (Teh $\mathrm{CH}$ ) upon reasonable request and with permission of the Director General of Health, Malaysia.

\section{Authors' contributions}

$\mathrm{TCH}$ as the first author, performed the laboratory tests, analyzed and interpreted the data, and drafted the manuscript. NHA helped to conduct GC-MS and analysed the results. NA helped to interpret the antibacterial assay's result and provided constructive comments. NWA and LHL reviewed and revised the manuscript critically for important intellectual content. All authors had given the final approval to publish this paper in its present form and were accountable for the accuracy and integrity of the content of this paper.

\section{Competing interests}

The authors declare that they have no competing interests.

Consent for publication

Not applicable.

Ethics approval and consent to participate

Not applicable.

Received: 13 December 2016 Accepted: 17 January 2017

Published online: 16 February 2017

\section{References}

1. Chernysh S, Kim SI, Bekker G, Pleskach VA, Filatova NA, Anikin VB, Platonov VG, Bulet P. Antiviral and antitumor peptides from insects. Proc Natl Acad Sci. 2002;99(20):12628-32.

2. Faraldo AC, Sa-Nunes A, Faccioli LH, Del Bel EA, Lello A. Nitric oxide synthase activity in tissues of the blowfly Chrysomya megacephala (Fabricius, 1794). Biocell. 2007;31(2):205-11.

3. Gahlaut A, Chhillar A.K. Evaluation of antibacterial potential of plant extracts using resazurin based microtiter dilution assay. International Journal of Pharmacy and Pharmaceutical Sciences. 2013;5(2):372-76.

4. Golebiowski M, Cerkowniak M, Urbanek A, Dawgul M, Kamysz W, Bogus MI, et al. Antimicrobial activity of untypical compounds in the cuticular and internal lipids of four fly species. J Appl Microbiol. 2013;116:269-87.

5. Hughes CC, Fenical W. Antibacterials from the sea. Chem. 2010;16:12512-25.

6. Hussain Al, Anwar F, Nigam PS, Sarker SD, Moore JE, Rao JR, Mazumdar A. Antibacterial activity of some Lamiaceae essential oils using resazurin as an indicator of cell growth. Food Science and Technology. 2011:44(4):11991206.

7. Ivanova E, Atanasova-Pancevska N, Kungulovski D. Antimicrobial activities of laboratory produced essential oil solutions against five selected fungal strains. J Nat Sci. 2013:124:171-83.

8. Karuppusamy S, Rajasekaran KM. High throughput antibacterial screening of plant extracts by resazurin redox with special reference to medicinal plants of Western Ghats. Glob J Pharmacol. 2009:3(2):63-8.

9. Kerridge A, Lappin-Scott H, Stevens JR. Antibacterial properties of larval secretions of the blowfly, Lucilia sericata. Med Vet Entomol. 2005;19:333-7.

10. Meylaers K, Clynen E, Daloze D, Deloof A, Schoofs L. Identification of 1-lysophosphatidylethanolamine $\left(C_{16: 1}\right)$ as an antimicrobial compound in the housefly, Musca domestica. Insect Biochem Mol Biol. 2004;34:43-9. 
11. Nagaraj R, Prakash M, Karmegam N. Antibacterial activity of Morinda umbellate L. (Rubiaceae) leaves by resazurin redox method. Int J Curr Res Biosci Plant Biol. 2014;1 (5):53-7.

12. O'Brien J, Wilson I, Orton T, Pognan F. Investigation of the Alamar Blue (resazurin) fluorescent dye for the assessment of mammalian cell cytotoxicity. Eur J Biochem. 2000;267:5421-6.

13. Paul AG, Ahmad NW, Lee HL, Ariff AM, Saranum M, Naicker AS, et al. Maggot debridement therapy with Lucilia cuprina: a comparison with conventional debridement in diabetic foot ulcers. Int Wound J. 2009; 6(1):39-46.

14. Pesch $\mathrm{KL}$, Simmert U. Combined assays for lactose and galactose by enzymatic reactions. Kieler Milchw Forsch. 1929;8:551.

15. Rahman H, Austin B, Mitchell WJ, Morris PC, Jamieson DJ, Adams DR, et al. Novel anti-infective compounds from marine bacteria. Mar Drugs. 2010;8:498-518

16. Ratcliffe NA, Rowley AF, Fitzgerald SW, Rhodes CP. Invertebrate immunity, basic concepts and recent advances. Int Rev Cytol. 1985:97:183-349.

17. Ravi C, Jeyashree A, Renuka DK. Antimicrobial peptides from insects: an overview. Res Biotechnol. 2011;2(5):1-7.

18. Sarker SD, Nahar L, Kumarasamy Y. Microtiter plate-based antibacterial assay incorporating resazurin as an indicator of cell growth, and its application in the in vitro antibacterial screening of phytochemicals. Methods. 2007;42: $321-24$

19. Teh $\mathrm{CH}$, Nazni WA, Lee HL, Fairuz A, Tan SB, Mohd SA. In vitro antibacterial activity and physicochemical properties of a crude methanol extract of the larvae of the blowfly Lucilia cuprina. Med Vet Entomol. 2013;27(4):414-20.

20. Thormar H. Lipids and Essentials Oils As Antimicrobial Agents. United Kingdom: Wiley; 2011.

21. World Health Organization: Antimicrobial Resistance: Global Report on Surveillance. 2014. http://apps.who.int/iris/bitstream/10665/112642/1/ 9789241564748_eng.pdf. Accessed 23 Jan 2017.

22. Zheng CJ, Yoo JS, Lee TG, Cho HY, Kim YH, Kim WG. Fatty acid synthesis is a target for antibacterial activity of unsaturated fatty acids. FEBS Lett. 2005; 579(23):5157-62.

\section{Submit your next manuscript to BioMed Central and we will help you at every step:}

- We accept pre-submission inquiries

- Our selector tool helps you to find the most relevant journal

- We provide round the clock customer support

- Convenient online submission

- Thorough peer review

- Inclusion in PubMed and all major indexing services

- Maximum visibility for your research

Submit your manuscript at www biomedcentral.com/submit

) Biomed Central 